\title{
Nepalese version of Douleur Neuropathique 4 (DN4) questionnaire for Assessment of Neuropathic pain: A Validation Study
}

Bigen M Shakya, ${ }^{1}$ Anil Shrestha, ${ }^{2}$ Amod K Poudyal, ${ }^{3}$ Ninadini Shrestha, ${ }^{4}$ Binita Acharya, ${ }^{5}$ Renu Gurung, ${ }^{6}$ Sujata Shakya ${ }^{7}$

${ }^{1}$ Associate Professor, bigen.shakya@mmc.tu.edu.np, Department of Anaesthesiology, Maharajgunj Medical Campus, Institute of Medicine, Tribhuvan University, Maharajgunj, Kathmandu, Nepal, ORCID ID: https://orcid.org/0000-0001-5000-1595.

${ }^{2}$ Associate Professor, anil.shrestha@mmc.tu.edu.np, Department of Anaesthesiology, Maharajgunj Medical Campus, Institute of Medicine, Tribhuvan University, Maharajgunj, Kathmandu, Nepal.

${ }^{3}$ Associate Professor, amod.poudyal@cdph.tu.edu.np, Central Department of Public Health, Tribhuvan University Institute of Medicine, Kathmandu, Nepal

${ }^{4}$ Assistant Professor, ninadinishrestha@iom.edu.np, Department of Anaesthesiology, Maharajgunj Medical Campus, Institute of Medicine, Tribhuvan University, Maharajgunj, Kathmandu, Nepal.

${ }^{5}$ Associate Professor, binita.acharya@mmc.tu.edu.np, Department of Anaesthesiology, Maharajgunj Medical Campus, Institute of Medicine, Tribhuvan University, Maharajgunj, Kathmandu, Nepal.

${ }^{6}$ Associate Professor, renu.gurung@mmc.tu.edu.np, Department of Anaesthesiology, Maharajgunj Medical Campus, Institute of Medicine, Tribhuvan University, Maharajgunj, Kathmandu, Nepal.

${ }^{7}$ Assistant Professor, sujata_8@iom.edu.np, MPH, Central Department of Public Health, Tribhuvan University Institute of Medicine, Kathmandu, Nepal, ORCID ID:

https://orcid.org/0000-0003-0341-595X.

Word Count: 2874

Word Count of abstract: 278

Number of tables: 6

Number of figures: 1

\section{Corresponding address:}

31 Sujata Shakya

3299 Lagan Chowk, Ward number 21, Bagmati

33 Kathmandu, Nepal

34 Contact number: +977-9841463678

35 Email address: sujata_8@iom.edu.np 
ORCID ID: https://orcid.org/0000-0003-0341-595X

\section{Abstract}

\section{Objective}

39 This study aimed to translate and validate DN4 questionnaire into Nepalese version.

40 Design

41 An observational study design was adopted.

\section{$42 \quad$ Setting}

43 A tertiary level teaching hospital of Kathmandu, Nepal

\section{$44 \quad$ Participants}

45 We included 166 purposively selected patients visiting pain clinics of the hospital over one year 46 time

\section{Methods}

48 The Nepalese version of the DN4 questionnaire was used to detect neuropathic pain among the

49 chronic pain patients of the hospital. The English version of the questionnaire was translated into

50 Nepali based on the standard guideline with the help of linguistic experts. The patients diagnosed

51 with nociceptive or neuropathic pain were interviewed twice in two weeks interval. We analyzed

52 test-retest reliability and strength of the test by using Intra-class correlation coefficient (ICC) and

53 Receiver Operating Characteristics (ROC) Curve, respectively. Internal Consistency reliability

54 was assessed using Cronbach's alpha ( $\infty$ ). Diagnostic accuracy was assessed through measures

55 like sensitivity, specificity, positive and negative predictive values, and positive and negative 56 likelihood ratio. 
medRxiv preprint doi: https://doi.org/10.1101/2021.09.17.21263734; this version posted September 21, 2021. The copyright holder for this preprint (which was not certified by peer review) is the author/funder, who has granted medRxiv a license to display the preprint in perpetuity.

It is made available under a CC-BY-NC 4.0 International license .

\section{Results}

59 The study showed a good test-retest reliability ( $\mathrm{ICC}=0.877)$ and internal consistency reliability 60 ( $\infty=0.710)$. The AUC were $0.932(0.894-0.971)$ for the first test, and $0.955(0.921-0.990)$ for the

61 second test. The sensitivity and specificity values were found highest at the 4 cut-off point (4

62 score out of 10 ), that are $75 \%$ and $95.3 \%$ for test 1 , and $76.2 \%$ and $98.8 \%$ for test 2 . Similarly

63 positive and negative predictive values are $93.8 \%$ and $80.4 \%$ respectively for the first test and

$64 \quad 98.4 \%$ and $81.7 \%$ respectively for the second test.

\section{Conclusions}

66 The Nepalese version of DN4 questionnaire is a valid and reliable tool for the diagnosis of 67 neuropathic pain. This can be used for screening neuropathic and non-neuropathic pain in 68 clinical as well as epidemiological settings.

69 Key words: Nepal; neuropathic pain; questionnaire; translate

\section{Article Summary}

\section{Strengths and Limitations of this Study}

72
- This study validated Nepalese version of DN4 questionnaire, so, it can be used as a standard tool to assess neuropathic pain among the Nepalese population.

- As interview was conducted with the patients, this might minimize the reliability and validity issue.

- This questionnaire is only applicable to those who can communicate properly in Nepalese language. 
medRxiv preprint doi: https://doi.org/10.1101/2021.09.17.21263734; this version posted September 21, 2021. The copyright holder for this preprint (which was not certified by peer review) is the author/funder, who has granted medRxiv a license to display the preprint in perpetuity.

It is made available under a CC-BY-NC 4.0 International license .

- There can be problem of understanding among the participants as few words do not have exact Nepali words with the same meaning.

\section{Introduction}

Neuropathic pain is defined as pain caused by a lesion or disease of the somatosensory nervous system (1). The diagnosis of neuropathic pain is complex, and it is based on clinical history, physical examination, and other advanced investigations. Since neuropathic pain is one of the prevalent health conditions, several questionnaires have been developed to facilitate its detection. They include Neuropathic pain Scale (2), Pain detect (3), Leeds Assessment of Neuropathic Symptoms and Signs (LANSS) (4), Douleur Neuropathique 4 (DN4). These screening tools consist of structured questions and may include a simple clinical examination. The detection of neuropathic pain can be done with a high degree of sensitivity and specificity with the aforementioned tools (5). Moreover, these tools can be used by a specialist as well as any health person (6).

Due to its popularity, the DN4 questionnaire has been translated and validated into various languages such as Hindi (7), Thai (8), Japanese (9), Korean (10), Spanish (11), Greek (12), Portuguese (13), Turkish (14) and so on. It was originally developed by French Neuropathic pain group in 2005 (15). This screening tool is simple to use and can be introduced in daily practice as well for epidemiological studies.

Translation of the standard questionnaire should preserve the meaning and intent of the original item, and its validity and reliability must be maintained. The process of translation and its adaptation to different cultural groups are demanding and time consuming. Without validation, translation of a questionnaire may lead to misleading conclusions, either in clinical practice and/or epidemiological studies. There exist guidelines for the translation and validation of tools 
medRxiv preprint doi: https://doi.org/10.1101/2021.09.17.21263734; this version posted September 21, 2021. The copyright holder for this preprint (which was not certified by peer review) is the author/funder, who has granted medRxiv a license to display the preprint in perpetuity.

It is made available under a CC-BY-NC 4.0 International license .

101 (16). Some of the standard tools, like Numerical Pain Rating Scale, have already been translated 102 and validated in Nepali language (17). Our aim is to translate and validate the DN4 questionnaire 103 according to the standard guideline. Once validated, this tool can be used as a screening tool by 104 any health personnel for the diagnosis of neuropathic pain.

105 Methods

106 Study Design

107 We conducted a prospective observational study among patients with chronic pain attending the 108 pain clinic of a tertiary level teaching hospital, Kathmandu, Nepal, over a period of one year 109 from February 2019 to January 2020.

110 Participants Selection

111 For the selection of participants, we adopted nonprobability purposive sampling technique and

112 included adult patients (18 years and above) who attended the pain clinic with chronic pain (pain

113 of duration more than 3 months) or who were referred from other departments for further

114 evaluation of chronic pain. Only those patients who could communicate in Nepalese language 115 were selected for the study. The excluded patients were those who had fibromyalgia, phantom 116 pain, headache, chronic visceral pain, cancer pain, and severe depression.

117 Due to the lack of consensus regarding the calculation of the sample size in validation studies, 118 the suggested ratio of subject to item ranges from 2-20 (18). The total sample size for this study 119 was 166, which was taken to make the subject-to-item ratio 16:1.

120 The ethical approval for the research was obtained from the Institutional Review Committee of 121 Institute of Medicine, Tribhuvan University [338(6-11) $\left.\mathrm{E}^{2} / 075 / 76\right]$. Written informed consent 122 was taken from the participants before data collection. 
medRxiv preprint doi: https://doi.org/10.1101/2021.09.17.21263734; this version posted September 21, 2021. The copyright holder for this preprint (which was not certified by peer review) is the author/funder, who has granted medRxiv a license to display the preprint in perpetuity.

It is made available under a CC-BY-NC 4.0 International license .

\section{Data Collection}

126 We used Nepalese version of the DN4 questionnaire among the chronic pain patients by using

127 interview technique to detect the neuropathic pain.

DN4 questionnaire

129 The DN4 questionnaire consists of 10 items, in which 7 items are related to pain characteristics

130 and 3 items are related to findings on physical examination of the painful areas. The cut-off

131 value for the diagnosis of neuropathic pain is 4/10. The area under the curve for the total score of

132 French version of the questionnaire is 0.92 . A cut-off score of 4 resulted in the highest percent of 133 sensitivity (82.9\%) and specificity (89.9\%). The inter-rater reliability (Cohen Kappa coefficient)

134 is between 0.70 and $0.96 .(15)$

135 We adopted guidelines given by Sperber AD for translation process.(16)

Phase 1: Translation and back-translation

137 The English version of DN4 questionnaire was translated into Nepalese version independently by

138 three individuals, two linguistic experts, and one neurologist who had experience in management

139 of chronic pain. These three individuals along with the principal investigator then discussed

140 issues during translation process and formed a preliminary draft of Nepalese version of the

141 questionnaire. The preliminary draft so formed was back translated to English version by another

142 translation expert who was not aware of the previous translation. The committee of three pain

143 specialists (Anaesthesiologists trained in management of chronic pain), along with the forward

144 and backward translators and a research expert discussed and reviewed the items of all versions 
medRxiv preprint doi: https://doi.org/10.1101/2021.09.17.21263734; this version posted September 21, 2021. The copyright holder for this preprint (which was not certified by peer review) is the author/funder, who has granted medRxiv a license to display the preprint in perpetuity.

It is made available under a CC-BY-NC 4.0 International license .

145 of translation and compared with the original English version for semantic, experiential and

146 conceptual equivalence. Finally, the pre-final Nepalese version of DN4 was formed.

147 Phase 2: Pretesting and modification

148 Pretesting of the pre-final Nepalese version was done among 25 patients with neuropathic pain

149 attending a private pain clinic situated in Kathmandu, Nepal. During the interview, the patients

150 were specifically asked "Do you understand about items listed in the questionnaire?". Depending

151 on the results of the pretest, the Nepali word for 'cold pain' was rephrased, and the final draft of

152 the Nepalese version of Dn4 questionnaire was prepared.

153 Face validity of the questionnaire was maintained by pretesting the pre-final version of the

154 translated Nepalese DN4 questionnaire among a small group of respondents. We found that all of

155 the pain descriptors were well understood by the respondents excluding the word 'cold pain.

156 Various possible words were explored which is closest to the word 'cold pain'. Finally, the word

word. The new translated word was retested in a small group of respondents, which showed the satisfactory results.

Content validity of the questionnaire was established by forming a panel of experts containing a

161 methodologist, a statistician and two pain specialists. The translated Nepalese version of the 162 questionnaire was compared with the previous English version and discussed among the experts.

163 The similarity of interpretability of words, phrases, and sentences were analyzed, and the 164 questionnaire was examined to find out whether the items adequately measure the intended 165 constructs and are sufficient to measure different domains. The translation was revised based on 166 consensus of all. 
medRxiv preprint doi: https://doi.org/10.1101/2021.09.17.21263734; this version posted September 21, 2021. The copyright holder for this preprint (which was not certified by peer review) is the author/funder, who has granted medRxiv a license to display the preprint in perpetuity.

It is made available under a CC-BY-NC 4.0 International license .

167

168

169

170

171

172

173

174

175

176

177 in French version (15).

\section{Test Methods}

We divided the patients with chronic pain into two groups (neuropathic and nociceptive) after examination by a pain specialist in the pain clinic. The diagnosis of neuropathic pain was made through the patient's history, clinical examination, and/or confirmatory tests (if applicable) based on the guidelines provided by International Association for the Study of Pain (IASP) which is the internationally accepted guideline (19). A pain specialist, who was not involved in the segregation of patients, then performed interviews on the same day using the final corrected Nepali version of DN4 questionnaire. Those patients were interviewed again within two weeks using the same questionnaire during the follow-up. We considered the cutoff value for leveling neuropathic pain by DN4 questionnaire as 4/10 and above. This cutoff was also originally used

\section{Statistical Analysis}

179 We entered the data into Microsoft Excel 2013 and then exported to SPSS version 16 for statistical analysis. Under descriptive statistics, mean, frequency and percentage were calculated. To compare the score of DN4 questionnaire with the nature of pain, chi-square test was performed. To assess the internal consistency reliability, Cronbach's alpha was calculated.

183 Cronbach's alpha of $\geq 0.7$ is considered adequate. (20) We used test-retest reliability to assess the correlation between two episodes of the test and derived Receiver Operating Characteristic (ROC) Curve for analyzing the discriminative ability of the test. Similarly, different diagnostic 186 values to detect neuropathic pain like sensitivity, specificity, positive and negative predictive

187 value, and positive and negative likelihood ratio were calculated. Any missing or indeterminate 188 test results were excluded from the study.

\section{Patient and Public Statement}


medRxiv preprint doi: https://doi.org/10.1101/2021.09.17.21263734; this version posted September 21, 2021. The copyright holder for this preprint (which was not certified by peer review) is the author/funder, who has granted medRxiv a license to display the preprint in perpetuity.

It is made available under a CC-BY-NC 4.0 International license .

190

191

192

193

194

195

196

197

198

199

200

201

203

204

205

206

207

No patient or public involvement was done during design, conduct, reporting or dissemination of the research. The patients attending pain clinic were involved as participants after obtaining written informed consent.

\section{Results}

The total participants attending the pain clinic during the period of the study was 216 . Out of these, 50 patients were excluded due to various reasons like cancer, headache, pain less than 3 months, phantom pain, and visceral pain. Thus, the total number of eligible participants enrolled in this study was 166 .

The general characteristics of the respondents are presented in Table 1 . The mean ages of the patients with nociceptive pain and neuropathic pain were $49.03 \pm 15.1$ and $52.79 \pm 14.8$ years respectively. More than two-third (67.4\%) were females.

Table 1. Baseline Characteristics

\begin{tabular}{llrr}
\hline Characteristics & & Nociceptive $(\mathbf{n}=\mathbf{8 6})$ & Neuropathic $(\mathbf{n}=\mathbf{8 0})$ \\
\hline Age (in years) & Mean age & $49.03 \pm 15.1$ & $52.79 \pm 14.8$ \\
Sex & Male & $28(32.6 \%)$ & $31(38.8 \%)$ \\
& Female & $58(67.4 \%)$ & $49(61.3 \%)$ \\
\hline
\end{tabular}

The most common symptoms in patients with neuropathic pain were tingling sensation (75.0\%), burning pain $(72.5 \%)$, needle sensation $(71.3 \%)$, and electrical pain $(71.3 \%)$ (Table 2). These symptoms were found significantly more among patients with neuropathic pain compared to those with nociceptive pain $(\mathrm{p}<0.001)$.

Table 2: Comparison of Items of DN4 Questionnaire between Neuropathic and Nociceptive conditions

\begin{tabular}{|c|c|c|c|c|c|}
\hline \multirow{3}{*}{ Items } & \multicolumn{2}{|c|}{ Nociceptive $(n=86)$} & \multicolumn{2}{|c|}{ Neuropathic $(n=80)$} & \multirow{3}{*}{ p value* } \\
\hline & Absent & Present & Absent & Present & \\
\hline & n $\%$ & n $\quad \%$ & n $\%$ & n $\quad \%$ & \\
\hline
\end{tabular}


medRxiv preprint doi: https://doi.org/10.1101/2021.09.17.21263734; this version posted September 21, 2021. The copyright holder for this preprint (which was not certified by peer review) is the author/funder, who has granted medRxiv a license to display the preprint in perpetuity.

It is made available under a CC-BY-NC 4.0 International license .

\begin{tabular}{lrrrrrrrrr}
\hline Burning & 61 & 70.9 & 25 & 29.1 & 22 & 27.5 & 58 & 72.5 & $<0.001$ \\
Cold pain & 79 & 91.8 & 7 & 8.1 & 66 & 82.5 & 14 & 17.5 & 0.7 \\
Electric pain & 74 & 86.0 & 12 & 14.0 & 23 & 28.8 & 57 & 71.3 & $<0.001$ \\
Tingling & 66 & 76.7 & 20 & 23.3 & 20 & 25.0 & 60 & 75.0 & $<0.001$ \\
Needle sensation & 56 & 65.1 & 30 & 34.9 & 23 & 28.8 & 57 & 71.3 & $<0.001$ \\
Numbness & 81 & 94.2 & 5 & 5.8 & 45 & 56.3 & 35 & 43.8 & $<0.001$ \\
Itching & 85 & 98.8 & 1 & 1.2 & 66 & 82.5 & 14 & 17.5 & $<0.001$ \\
Decreased sense on touch & 84 & 97.7 & 2 & 2.3 & 53 & 66.3 & 27 & 33.8 & $<0.001$ \\
Decreased sense on pin pick & 86 & 100.0 & 0 & 0 & 56 & 70.0 & 24 & 30.0 & $<0.001$ \\
Increased pain on brushing & 83 & 96.5 & 3 & 3.5 & 55 & 68.8 & 25 & 31.3 & $<0.001$ \\
\hline
\end{tabular}

*Chi-square test

\begin{tabular}{|c|c|c|c|c|c|c|}
\hline & \multicolumn{6}{|c|}{ Diagnosis of pain } \\
\hline & & \multicolumn{2}{|c|}{ Nociceptive $(n=86)$} & \multicolumn{2}{|c|}{ Neuropathic $(\mathbf{n}=\mathbf{8 0})$} & \multirow[t]{2}{*}{ p value* } \\
\hline & & $\mathbf{n}$ & $\%$ & n & $\%$ & \\
\hline \multirow[t]{2}{*}{ DN4 first time } & Negative & 82 & 80.4 & 20 & 19.6 & $<0.001$ \\
\hline & Positive & 4 & 6.3 & 60 & 93.8 & \\
\hline \multirow{2}{*}{ DN4 second time } & Negative & 85 & 81.7 & 19 & 18.3 & $<0.001$ \\
\hline & Positive & 1 & 1.6 & 61 & 98.4 & \\
\hline
\end{tabular}

Table 3 compares the pain assessment using DN4 questionnaire with the diagnosis of pain. It

shows a highly significant association between the two scores of DN4 questionnaire and the

211 actual diagnosis of pain $(\mathrm{p}<0.001)$.

Table 3. Comparison of the score of DN4 questionnaire with diagnosis of pain

*Chi-square test

214 Internal Consistency Reliability (Chronbach's alpha)

215 The Cronbach's alpha $(\infty)$ coefficient of the entire DN4 questionnaire is found to be 0.710 ,

216 indicating adequate internal consistency. The coefficient value was not much difference by

217 removing any of the items in the questionnaire. Thus, all questions were included in the DN4

218 questionnaire (Table 4).

Table 4: Internal Consistency Reliability 


\begin{tabular}{lccr}
\hline Item & Cronbach's $\infty$ & ICC (95\% CI) & \multicolumn{2}{c}{$\begin{array}{l}\text { Cronbach's } \infty \\
\text { (if single item deleted) }\end{array}$} \\
\hline Burning & 0.710 & $0.640-0.772$ & 0.689 \\
Cold pain & & 0.728 \\
Electric pain & & 0.677 \\
Tingling & & 0.656 \\
Needle sensation & & 0.710 \\
Numbness & & 0.664 \\
Itching & & 0.701 \\
Decreased sense on touch & & 0.660 \\
Decreased sense on pin pick & & 0.661 \\
Increased pain on brushing & & 0.719 \\
\hline ICC = Intra-class Correlation Coefficient & &
\end{tabular}

\begin{tabular}{llll}
\hline & Test $($ Mean \pm SD) & Re-test $(M e a n \pm$ SD) & ICC (95\% CI) \\
\hline Retest sample $(\mathbf{n = 1 6 6 )}$ & $3.06 \pm 2.293$ & $2.74 \pm 2.235$ & $0.948(0.921-0.964)^{*}$ \\
NP $(\mathbf{n = 8 0})$ & $4.79 \pm 1.874$ & $4.55 \pm 1.764$ & $0.877(0.807-0.921)^{*}$ \\
NNP (86) & $1.45 \pm 1.233$ & $1.06 \pm 0.925$ & $0.858(0.689-0.925)^{*}$ \\
\hline
\end{tabular}

The patients were interviewed twice using the Nepalese version of DN4 questionnaire, once

223 during their first visit at the pain clinic, and again within 2 weeks. The test-retest reliability was

224 measured by calculating intra-class correlation coefficient, which was found to be more than 0.8 ,

225 indicating a good test-retest reliability value (Table 5).

$227 \mathrm{NP}=$ Neuropathic Pain, NNP = Non-neuropathic Pain, ICC $=$ Intra-class Correlation Coefficient, $* \mathrm{p}<0.001(\mathrm{p}$ value 228 for intra-class correlation coefficient)

\section{Receiver Operating Characteristics Curve (ROC) Analysis}

230 The clinical diagnosis was used as the reference for the calculation of Area under the Curve 231 (AUC). Figure 1 represents the ROC curve for two episodes of the test using Nepali version of 232 DN4 questionnaire. The AUCs for the two episodes of test were 0.932 with $95 \%$ CI (0.894 to $0.971)$ and 0.955 with $95 \%$ CI (0.921-0.990), which signifies a strong test. 
medRxiv preprint doi: https://doi.org/10.1101/2021.09.17.21263734; this version posted September 21, 2021. The copyright holder for this preprint (which was not certified by peer review) is the author/funder, who has granted medRxiv a license to display the preprint in perpetuity.

It is made available under a CC-BY-NC 4.0 International license .

234 The sensitivity and specificity values for the two episodes of the test were found highest at the 235 cut-off level of 4, which was also used in the original DN4 questionnaire. Similarly, other 236 measures like Youden index, positive and negative predictive values, etc were also calculated 237 (Table 6).

Table 6. Diagnostic Values of the DN4 questionnaire for the Discrimination of Neuropathic Pain

\begin{tabular}{|c|c|c|c|c|c|c|c|}
\hline Test Result & $\begin{array}{l}\text { Youden } \\
\text { index }\end{array}$ & Sensitivity (\%) & Specificity (\%) & PPV (\%)I & $(\%) \mathrm{I}$ & $\mathbf{R}(\%) \mathrm{I}$ & $(\%)$ \\
\hline Test 1 & 0.7 & 75.0 & 95.3 & 93.8 & 80.4 & 15.96 & 0.26 \\
\hline Test 2 & 0.75 & 76.2 & 98.8 & 98.4 & 81.7 & 63.5 & 0.24 \\
\hline
\end{tabular}
Likelihood Ratio

\section{Discussion}

This study was conducted at one of the academic institutes of Nepal among 166 patients who were referred to the pain clinic. The Nepali version of DN4 questionnaire was tested on the patients. The test-retest reliability was determined, along with AUC analysis and calculation of sensitivity, specificity, positive and negative predictive values with a cutoff value of 4 , which was also originally used in French version (15). DN4 questionnaire was first created by French neuropathic team and was originally in French language. Due to its simplistic nature, the questionnaire has been translated into various other languages. However, translation can be a complicated process. The major hurdle is the fact that every language has its own unique nuances, grammatical rules, vocabulary, and so on. Rendering ideas from one language to another while also keeping the essence intact is a difficult task with a simple translation. The 
medRxiv preprint doi: https://doi.org/10.1101/2021.09.17.21263734; this version posted September 21, 2021. The copyright holder for this preprint (which was not certified by peer review) is the author/funder, who has granted medRxiv a license to display the preprint in perpetuity.

It is made available under a CC-BY-NC 4.0 International license .

256

257

258

259

260

261

262

263

264

265

266

267

268

269

270

271

272

273

274

275

276

277

278

issues that could be encountered during translation of questionnaires were well discussed in the study by Seventer et al. (21). The authors described three situations: the original word can be literally translated, the word might need added explanation, or a different word that retains the intended meaning has to be used. For interpreting this questionnaire into Nepali language, we have conformed to the universal guidelines for translating questionnaires.

The first time we encountered a problem was while we were trying to restate questions 1 and 2 in Nepali. [Question 1: Does the pain have one or more of the following characteristics? Question 2: Is the pain associated with one or more of the following symptoms in the same area?] Due to the inherent discrepancies in the grammatical rules and lexicons of the two languages, achieving a direct rendering of the aforementioned questions proved infeasible. With the aid of two interpreters and clinical staff, we managed to come up with restatements that are close in meaning to the original questions, but also in line with the conventions of the Nepali language which Nepalese people can easily comprehend. Of all the items listed in the questionnaire, 'cold pain' was the most difficult term to properly translate. All other items except this term have Nepali equivalents. For this reason, we had to think of a phrase that conveyed the same meaning as 'cold pain'. Most of the patients in the study actually believed that this kind of pain is aggravated by cold weather. Upon asking the question "Do you understand what it means?", we identified this common misconception. For this reason, caution must be exercised while asking the patient about cold pain. In the Hindi version of DN4 questionnaire also, cold pain was present in only $14 \%$ of patients with neuropathic pain (7). In our study, only $17 \%$ of patients with neuropathic pain had symptoms of cold pain.

While interviewing twice using the Nepali version of the questionnaire, it showed a good testretest reliability value $(\mathrm{ICC}=8)$. In the same way, the New Arabic version (22) of the 
medRxiv preprint doi: https://doi.org/10.1101/2021.09.17.21263734; this version posted September 21, 2021. The copyright holder for this preprint (which was not certified by peer review) is the author/funder, who has granted medRxiv a license to display the preprint in perpetuity.

It is made available under a CC-BY-NC 4.0 International license .

279 questionnaire also showed excellent test-retest reliability (ICC >9). The test-retest intraclass

280 correlation coefficient (95\% CI) of the Japanese version was 0.827 (0.769-0.870) (9). Similarly,

281 in our study, the AUC values for tests 1 and 2 were 0.932 with 95\% CI (0.894-0.971) and 0.955

282 with 95\% CI (0.921-0.990) respectively. The sensitivity and specificity of our version of the

283 questionnaire were $75 \%$ and $95.3 \%$, respectively, for test 1 , and $76.2 \%$ and $98.8 \%$, respectively,

284 for test 2, which were the highest at the cut-off value 4 or more. This finding is in accordance

285 with most of the validation studies $(7,9,11)$. There are, however, validations done in Dutch (23)

286 and New Arabic (22) languages, and both found the cutoff value at 5/10.

287 Based on our study, the most frequent complaints that patients with neuropathic pain had were

288 burning pain, electrical sensation, tingling sensation, and numbness. When this is compared with

289 other studies, we found variations $(7,22,23)$. We believe that neuropathic pain consists of a

290 collection of symptoms and signs that may also depend on the type of disease, so rather than

291 focusing on any specific item for predicting neuropathic pain, one must consider the cutoff value.

292 As per our study, a cutoff point of $4 / 10$ is the best for predicting neuropathic pain.

293 Our sample consisted of both literate and illiterate patients (those who could communicate in

294 Nepali language). However, we did not face any difficulties during the interviews, and the results

295 were also very similar. This study can validate Nepali version of DN4 questionnaire so that it can

296 be used as a standard tool to assess neuropathic pain among the Nepalese population. As the

297 interview was conducted with the patients, this minimizes the reliability and validity issue that

298 can occur in the case of a self-administered questionnaire. However, there were few limitations

299 too. The patients were first seen by a pain physician who was not involved in the interview. He

300 used clinical judgment for clinical diagnosis of pain. Other investigations could not be carried

301 out due to financial constraints of the patients. Importantly, the institutional policy did not permit 
medRxiv preprint doi: https://doi.org/10.1101/2021.09.17.21263734; this version posted September 21, 2021. The copyright holder for this preprint (which was not certified by peer review) is the author/funder, who has granted medRxiv a license to display the preprint in perpetuity.

It is made available under a CC-BY-NC 4.0 International license .

302 such investigations just for the sake of research. The same clinical diagnosis was used as

303 reference for the calculation of the data. Besides, Nepal is a small country, but with multicultural

304 and multilinguistic population. Thus, this questionnaire is only applicable to those who can

305 communicate properly in Nepali language. There can be a problem of understanding among the

306 participants as few words do not have an exact Nepali language with the same meaning, for

307 instance, 'cold pain'.

\section{Conclusion}

309 The Nepalese version of DN4 questionnaire has been validated and can be used as a screening

310 tool for predicting neuropathic pain in patients with chronic pain who can communicate well in

311 Nepali.

\section{Acknowledgements}

313 We would like to thank Mr. Laxman Rajbanshi (MA in Political Science) and Mr. Tirtha Ratna

314 Shakya (MA) and Dr. Sarbottan Shrestha (Neurologist) for translating the questionnaire into

315 Nepali and Mr. Sandesh Shakya (MA in English) for back translation. We would also like to

316 thank the hospital and the patients who participated in the study

\section{Author Contributions}

318 The corresponding author attests that all the following listed authors meet authorship criteria, and

319 no others meeting the criteria have been omitted.

320 BMS: study concept and design, literature review, manuscript writing, review and editing

321 AS: literature review, manuscript review

322 AKP: data analysis, manuscript review

323 NS: data collection, literature review, manuscript review 
medRxiv preprint doi: https://doi.org/10.1101/2021.09.17.21263734; this version posted September 21, 2021. The copyright holder for this preprint (which was not certified by peer review) is the author/funder, who has granted medRxiv a license to display the preprint in perpetuity.

It is made available under a CC-BY-NC 4.0 International license .

324 BA: data collection, literature review, manuscript review

325 RG: data collection, literature review, manuscript review

326 SS: data analysis, manuscript writing and editing

327

328

$329 \quad$ Funding

330 This research received no specific grant from any funding agency in the public, commercial, or

331 non-profit sectors.

332 Competing Interests

333 None declared

334 Patient consent for publication

335 Not required

336 Ethical approval

337 The ethical approval for the study was obtained from the Institutional Review Committee of,

338 Tribhuvan University, Institute of Medicine, Nepal (338(6-11)E²/075/76).

339 Data availability statement

340 The raw data can be made available upon genuine request.

341 Supplementary Material 
medRxiv preprint doi: https://doi.org/10.1101/2021.09.17.21263734; this version posted September 21, 2021. The copyright holder for this preprint (which was not certified by peer review) is the author/funder, who has granted medRxiv a license to display the preprint in perpetuity.

It is made available under a CC-BY-NC 4.0 International license .

342 The supplementary file consists of STARD checklist showing whether the required information

343 has been included in manuscripts submitted for publication. It also includes the diagram showing

344 the flow of participants through the study.

345 References

346 1. IASP. IASP Terminology [Internet]. 2017 [cited 2019 Oct 10]. Available from: https://www.iasp-pain.org/Education/Content.aspx?ItemNumber=1698

2. Galer BS, Jensen MP. Development and preliminary validation of a pain measure specific to neuropathic pain: The Neuropathic Pain Scale. Neurology. 1997;48(2):332-8.

350

351

352

353

354

355

356

357

358

359

360

361

3. Freynhagen R, Baron R, Gockel U, Tölle TR. painDETECT: A new screening questionnaire to identify neuropathic components in patients with back pain. Curr Med Res Opin. 2006;22(10):1911-20.

4. Bennett MI, Smith BH, Torrance N, Potter J. The S-LANSS score for identifying pain of predominantly neuropathic origin: Validation for use in clinical and postal research. $\mathbf{J}$ Pain. 2005;6(3):149-58.

5. Mathieson S, Maher CG, Terwee CB, Folly De Campos T, Lin CWC. Neuropathic pain screening questionnaires have limited measurement properties. A systematic review. J Clin Epidemiol [Internet]. 2015;68(8):957-66. Available from: http://dx.doi.org/10.1016/j.jclinepi.2015.03.010

6. Bennett MI, Attal N, Backonja MM, Baron R, Bouhassira D, Freynhagen R, et al. Using screening tools to identify neuropathic pain. Pain. 2007;127(3):199-203.

7. Gudala K, Ghai B, Bansal D. Hindi version of short form of douleur neuropathique 4 (S- 
medRxiv preprint doi: https://doi.org/10.1101/2021.09.17.21263734; this version posted September 21, 2021. The copyright holder for this preprint (which was not certified by peer review) is the author/funder, who has granted medRxiv a license to display the preprint in perpetuity.

It is made available under a CC-BY-NC 4.0 International license .

DN4) questionnaire for assessment of neuropathic pain component: A cross-cultural validation study. Korean J Pain. 2017;30(3):197-206.

8. Chaudakshetrin P, Prateepavanich P, Chira-Adisai W, Tassanawipas W, Leechavengvongs S, Kitisomprayoonkul W. Cross-cultural adaptation to the Thai language of the neuropathic pain diagnostic questionnaire (DN4). J Med Assoc Thail. 2007;90(9):1860-5.

9. Matsuki Y, Sukenaga N, Miyagi K, Tsunetoh T, Mizogami M, Shigemi K, et al. Reliability and validity of the Japanese translation of the DN4 Diagnostic Questionnaire in patients with neuropathic pain. J Anesth [Internet]. 2018;32(3):403-8. Available from: https://doi.org/10.1007/s00540-018-2495-7

10. Kim HJ, Park JH, Bouhassira D, Shin JH, Chang BS, Lee CK, et al. Validation of the Korean version of the DN4 diagnostic questionnaire for neuropathic pain in patients with lumbar or lumbar-radicular pain. Yonsei Med J. 2016;57(2):449-54.

11. Perez C, Galvez R, Huelbes S, Insausti J, Bouhassira D, Diaz S, et al. Validity and reliability of the Spanish version of the DN4 (Douleur Neuropathique 4 questions) questionnaire for differential diagnosis of pain syndromes associated to a neuropathic or somatic component. Health Qual Life Outcomes. 2007;5:1-10.

12. Sykioti P, Zis P, Vadalouca A, Siafaka I, Argyra E, Bouhassira D, et al. Validation of the Greek Version of the DN4 Diagnostic Questionnaire for Neuropathic Pain. Pain Pract. $2015 ; 15(7): 627-32$.

13. Santos JG, Brito JO, de Andrade DC, Kaziyama VM, Ferreira KA, Souza I, et al. Translation to Portuguese and Validation of the Douleur Neuropathique 4 Questionnaire. J Pain. 2010;11(5):484-90. 
medRxiv preprint doi: https://doi.org/10.1101/2021.09.17.21263734; this version posted September 21, 2021. The copyright holder for this preprint (which was not certified by peer review) is the author/funder, who has granted medRxiv a license to display the preprint in perpetuity.

It is made available under a CC-BY-NC 4.0 International license .

385

386

387

388

389

390

391

392

393

394

395

396

397

398

399

400

401

402

403

404

405

14. Unal-Cevik I, Sarioglu-Ay S, Evcik D. A comparison of the DN4 and LANSS questionnaires in the assessment of neuropathic pain: Validity and reliability of the turkish version of DN4. J Pain [Internet]. 2010;11(11):1129-35. Available from: http://dx.doi.org/10.1016/j.jpain.2010.02.003

15. Bouhassira D, Attal N, Alchaar H, Boureau F, Brochet B, Bruxelle J, et al. Comparison of pain syndromes associated with nervous or somatic lesions and development of a new neuropathic pain diagnostic questionnaire (DN4). Pain. 2005;114(1-2):29-36.

16. Sperber AD. Translation and Validation of Study Instruments for Cross-Cultural Research. Gastroenterology. 2004;126(1):124-8.

17. Sharma S, Palanchoke J, Reed D, Haxby Abbott J. Translation, cross-cultural adaptation and psychometric properties of the Nepali versions of numerical pain rating scale and global rating of change. Health Qual Life Outcomes. 2017;15(1):1-11.

18. Anthoine E, Moret L, Regnault A, Sbille V, Hardouin JB. Sample size used to validate a scale: A review of publications on newly-developed patient reported outcomes measures. Health Qual Life Outcomes. 2014;12(1):1-10.

19. Finnerup N, Haroutounian S, Kamerman P, Baron R, Bennett D, Bouhassira D, et al. Neuropathic pain: an updated grading system for research and clinical practice. Essence Analg Analg. 2010;157(8):30-7.

20. Nunnally J. Psychometric Theory. New York: McGraw $\square$ Hill; 1978.

21. Seventer R, Vos C, Meerding W, Mear I, Gal M, Bouhassira D, et al. Linguistic validation of the DN4 for use in international studies. Eur J Pain [Internet]. 2010;14(1):58-63. 
medRxiv preprint doi: https://doi.org/10.1101/2021.09.17.21263734; this version posted September 21, 2021. The copyright holder for this preprint (which was not certified by peer review) is the author/funder, who has granted medRxiv a license to display the preprint in perpetuity. It is made available under a CC-BY-NC 4.0 International license .

407 22. Chatila N, Pereira B, Maarrawi J, Dallel R. Validation of a New Arabic Version of the 408 Neuropathic Pain Diagnostic Questionnaire (DN4). Pain Pract. 2017;17(1):78-87.

409 23. Timmerman H, Steegers MAH, Huygen FJPM, Goeman JJ, Van Dasselaar NT, Schenkels

410 MJ, et al. Investigating the validity of the DN4 in a consecutive population of patients $411 \quad$ with chronic pain. PLoS One. 2017;12(11):1-21. 
medRxiv preprint doi: https://doi.org/10.1101/2021.09.17.21263734; this version posted September 21, 2021. The copyright holder for this preprint (which was not certified by peer review) is the author/funder, who has granted medRxiv a license to display the preprint in perpetuity.

It is made available under a CC-BY-NC 4.0 International license.
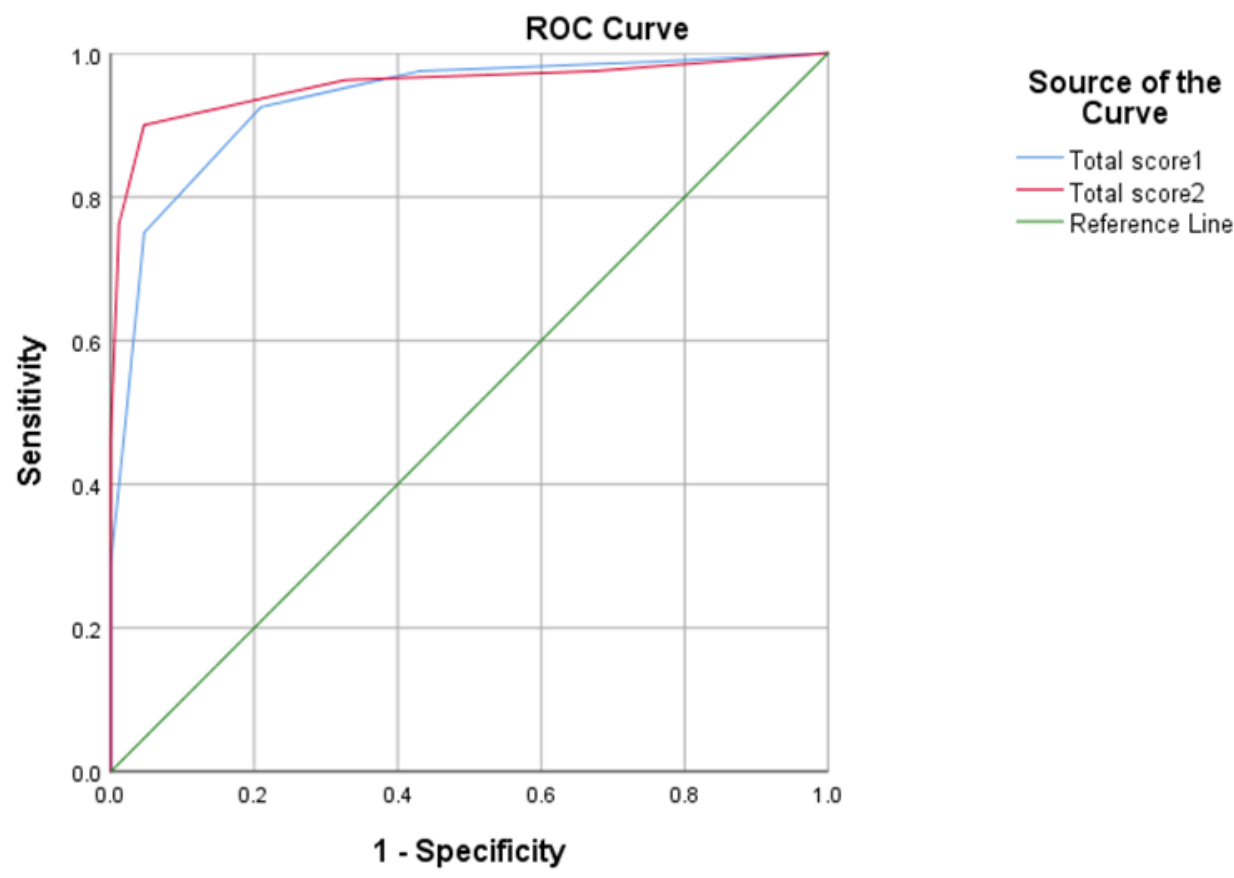

Diagonal segments are produced by ties.

AUC $($ Test 1$)=0.932(95 \%$ CI: 0.894-0.971)

AUC (Test 2) $=0.955(95 \%$ CI: 0.921-0.990)

Figure 1. Receiving-operator characteristic (ROC) curve for the total score of DN4 